\title{
Apprentice pay in Britain, Germany and Switzerland: Institutions, market forces and market power
}

\author{
Paul Ryan \\ University of Cambridge, UK \\ Uschi Backes-Gellner \\ Universität Zürich, Switzerland \\ Silvia Teuber \\ Universität Zürich, Switzerland \\ Karin Wagner \\ Hochschule für Technik und Wirtschaft Berlin, Germany
}

Corresponding author:

Paul Ryan, King's College, Cambridge CB2 1ST, UK

Email: paul.ryan@kings.cam.ac.uk

\begin{abstract}
The pay of metalworking apprentices is high in Britain, middling in Germany and low in Switzerland. We analyse these differences using fieldwork evidence and survey data, drawing on both economic and institutionalist theories. Several institutional attributes influence apprentice pay, partly by affecting supply and demand in markets for training places. Institutional support for apprenticeship training appears to involve important complementarities in both Germany and Switzerland, in contrast to Britain's less coherent and more market-driven approach.
\end{abstract}

\section{Keywords}

Apprenticeship training, pay structure, trade unions, employers' associations, monopsony power, collective bargaining, training contracts, public subsidies, education systems.

\section{May 2013}

Forthcoming, European Journal of Industrial Relations 


\section{Introduction}

Trainee pay is central to the economics of work-based training, dividing the cost between the employer and the trainee, and thus influencing incentives to offer and to undertake training. It is a recurrent matter of policy interest, as seen in calls in Britain and Germany for apprentice pay to be cut in order to increase training volume (Steedman, 2008; Wagner, 1999; Woessman, 2004). German governments, at both federal and Land levels, have encouraged employers to offer more training in return for trade union acceptance of lower apprentice pay (BMBF, 1999; Hyman, 2001: 137-40). This is however controversial: both the effectiveness and the feasibility of cuts in apprentice pay have been questioned (Acemoglu and Pischke, 1999; Beicht, 2011; Garonna and Ryan, 1991).

The first line of research of potential relevance to an understanding of trainee pay is human capital theory. Economists typically assume that trainee pay is set competitively, by clearing the market for training places (Becker, 1964). However, human capital theory does not readily explain differences between countries in the attributes of work-based training. Institutionalists focus specifically on such issues, relating national outcomes to the collective organization of employers and employees, and to national political systems. They have however paid little attention to the role of trainee pay in national systems of skill formation (Busemeyer and Trampusch, 2012; Hall and Soskice, 2001).

This article examines apprenticeship, the longest and costliest form of work-based training, which combines work-based learning with vocational education and is subject to externally mandated training standards. We consider three countries, Britain, Germany and Switzerland, with marked institutional differences. We focus on metalworking, in which apprenticeship provides in all three countries the principal route to intermediate skills, and does so with exceptional similarity of training standards. In that sector, apprentice pay as a proportion of that of skilled workers stood (around 2005) at 40.9, 29.2 and 14.1 percent in Britain, Germany and Switzerland respectively, a pattern that paralleled that in the economy as a whole (Ryan et al., 2011: Table 23). We use our fieldwork and national survey data to analyse these substantial differences.

We first discuss theories of apprentice pay, followed by research context and methods, and then present evidence on pay-setting and outcomes. Twelve potential determinants are considered, grouped and used for pair-wise comparative analysis. More detail is provided in Ryan et al. (2010, 2011).

\section{Theoretical framework}

\section{Human capital theory}

In economic theory, trainee pay is determined by the amount and type of skill learned, and by the balance of supply and demand in 'training markets': labour markets that implicitly contain opportunities to learn that skill. Three factors potentially change the demand and supply curves in training markets, and thus the price at which the market clears: the nature of the skill, the demand for trainees by employers, and the supply of potential trainees.

Assuming perfect competition in all markets --- if skills are 'general' --- trainee pay adjusts so as to allocate the entire cost of training to the trainee. Any investment that a firm makes in its trainees' skills has to be recouped by underpaying its skilled workers, creating an incentive for them to quit, which in turn denies the firm a return on its investment. For a costly skill, trainee pay is therefore low (Becker, 1964). Assuming diversity in both production technologies and youth occupational preferences, differences in demand and supply conditions affect trainee pay. If more employers require the skill, the demand for trainees is higher, and (ceteris paribus) so is trainee pay. If more qualified young people seek training, supply is higher, and trainee pay therefore lower. These factors potentially vary by company, sector, occupation and country. 
The assumption that the pay of skilled employers is set by competitive market clearing has become less central to human capital theory. Post-Becker variants commonly assume that employers have monopsony (buyer) power over their skilled employees, reflecting inter alia the cost to employees of finding and moving to another job. The firm then pays its skilled workers less than the value of their output, which requires it to pay its trainees more than it would under perfect competition for skilled workers --- and it can now do so without facing an excessive reduction in the return on its investment (Stevens, 1994).

However, most such models still assume that the market for training places is perfectly competitive and trainee pay is set by market-clearing (Leuven, 2005; Stevens, 1999). Some do assume that pay is negotiated by trade unions, which are assumed to seek lower pay inequality between members, resulting in an exogenous, supra-competitive wage floor for trainees (Acemoglu and Pischke, 1999). However, unions might be expected instead to bargain more strongly for skilled workers than for trainees, in which case trade unionism would be associated with lower (relative) trainee pay. Moreover, in the absence of collective bargaining, employers might enjoy monopsony power over trainees, not just skilled employees, leading to lower trainee pay than under perfect competition (Backes-Gellner and Mohrenweiser, 2010; Mühlemann et al., 2013; Wolter and Ryan, 2011).

Taken as a whole, human capital theory predicts that the pay of apprentices will be low in markets for training places when the total cost of training is high; when the productivity and pay of skilled workers are high (as trainees can then anticipate a high return to training); when the demand for skill by employers is low; when the supply of young people interested in and eligible for training for the occupation is high; and, under non-competitive pay setting, when either trade unions do not seek higher relative pay for trainees or employers possess monopsony power over trainees.

\section{Institutional theory}

Although human capital theory treats trainee pay as a central variable, it cannot explain why it and other attributes of apprenticeship vary greatly across countries (Wolter and Ryan, 2011). 'Varieties of Capitalism' and related institutionalist approaches see apprenticeship as depending on institutional support, specifically from employers' associations, trade unions and collective bargaining (Hall and Soskice, 2001; Crouch et al., 2001; Streeck and Yamamura, 2001; Thelen, 2004). Little attention has been paid to trainee pay, however, despite interest in the economic incentive to agents to offer and accept training (Busemeyer and Trampusch, 2012; Soskice, 1994; Trampusch, 2010). Nor do wider studies of employment relations consider trainee pay among the potential effects of collective organization by employees and employers (Hyman, 1999; Traxler et al., 2001).

Some development of institutionalist analysis is therefore required. We start from the dichotomy between coordinated and liberal market economies (CMEs and LMEs). The key difference in relation to apprenticeship is the extent to which training-related actions involve simply decentralized decisions based on rational self-interest, as is assumed for LMEs, including the UK, or are influenced, whether by exhortation, pressure or constraint by collective interests (employers' associations and chambers, trade unions and works councils) and by state bodies, as is assumed for CMEs, including Germany.

Apprentice pay is expected to depend in LMEs primarily on the balance of supply and demand in markets for training places. We therefore hypothesise that, as youth joblessness is particularly high in LMEs, apprentice pay will be lower in countries such as the UK, where trainee pay should be affected more strongly by youth competition for training places (Popiunik and Ryan, 2012). In CMEs, including Germany and Switzerland, apprentice pay is expected to depend not on simple market competition but rather on the power and goals of the representatives of employers and employees, and on the public institutions, particularly education systems, which jointly affect the demand for and supply of eligible and interested young people. 
What are the expected objectives of representatives of employers and employees? Employers would prefer low apprentice pay, to minimize training costs. As we focus on relative pay, this should hold for larger and smaller companies alike. The interests of employee representatives are more complex. The goals of unions and works councils may not include high pay for trainees. Low apprentice pay might be preferred when apprentices are few or weakly organized within the membership; when the recruitment of new members is not a priority; when employers do not use apprentices as cheap labour; and when unions want more training opportunities for young people (Ryan, 1987).

We therefore hypothesise that apprentice pay will be lower among CMEs: first, when employers' associations are more powerful than unions and works councils in the meso-level bodies that regulate training, including pay setting; and, second, when the balance of power between the two sides is less unequal, but unions and councils accept low apprentice pay in order to increase the supply of training by employers.

Finally, the interests and actions of public agents potentially affect apprentice pay (Crouch et al., 1999: 109-34). Governments in many countries, including the three studied here, promote apprenticeship training. The scale and effectiveness of those efforts may however differ. We hypothesise that in CMEs public policy is geared more systematically than in LMEs to the institutional buttressing of apprenticeship, including the promotion of lower apprentice pay, whether directly or indirectly. The ways in which governments may pursue that goal include social partnership, financial subsidies to training, the legal attributes of apprenticeship contracts, and the functioning of the education system.

An institutionalist approach therefore adds to the microeconomic incentives emphasised by human capital theory a role for collective action as influencing apprentice pay, both through market forces and despite them.

\section{Focus and context}

We focus on apprenticeship for intermediate (traditionally, craft and technician) skills in metalworking in Britain, Germany and Switzerland. Our country choice is motivated by large differences in apprentice pay (above); our choice of sector and occupation, by the similarity in metalworking of training content across the three countries and the importance of metalworking skills for economic performance.

The ratio of apprentices to employment in the economy as a whole in 2007-08 was only 0.7 per cent in Britain (England, Level 3 only), as compared to 6.5 and 4.8 per cent in in Germany and Switzerland (Ryan et al., 2011: Table 8). British programmes have less educational content and lower training standards than German and Swiss ones (Steedman, 2010). In metalworking, cross-national differences are smaller. The apprentice-employment ratio is 2.4, 5.8 and 4.9 per cent in Britain, Germany and Switzerland, respectively. ${ }^{1}$ Also, the quality of training differs little by country. In all three countries apprenticeship lasts 3.5 to 4 years, ordinances governing the content of its work-based component are set by external, publicly empowered bodies, and first-year apprentices spend at least 80 per cent of their time away from production.

\section{Sources of evidence}

Our evidence comes primarily from on-site interviews conducted between April 2008 and May 2009 in twenty-four plants with senior managers, mostly in human resources/personnel functions (Table 1). We also interviewed officials of sectoral trade unions and employers' associations, and representatives of government and other interested organizations. Target plants were matched across countries, choosing products (four-digit SIC code) for which comparable plants existed in all three: 
pumps, turbines, compressors and transport control systems. The plants comprise a variety of product lines and batch sizes, ranging from large batches of small pumps to one-off large turbines.

Our sample is dominated by mid-sized plants owned by large transnational companies and accounting by country for between five and eleven per cent of parent employment (Table 1). Thirteen are owned by companies that operate at least one of the other plants in the sample, in one or both of the other countries. Although actually training apprentices was not a condition for inclusion, all 24 plants do so. The plants are regionally concentrated in all countries: in England, in western Germany and in German-speaking Swiss cantons. The volume of training, measured by the average ratio of apprentices to production employees in the relevant occupation, is similar in the British and German samples (7.2 and 7.8 per cent) but higher in Switzerland (12.8 per cent), and in all three countries higher than the mean in metalworking as a whole. High standard deviations indicate large differences in training volume between plants in each country.

Table 1 about here

\section{Apprentice pay in sample companies}

Pay is measured here as base rates, excluding overtime, performance bonuses and additional (13th month) pay. ${ }^{2}$ In pursuit of valid comparisons across time and place, apprentice pay is measured, here as elsewhere, in relative terms, as a percentage of skilled pay in the same sector and occupation. In our sample too, apprentice pay varies greatly by country. In the Swiss plants, apprentices receive on average 19.5 per cent of skilled pay, as against 33.4 per cent in Germany and 63.5 per cent in Britain. These inter-country differences exceed those in national surveys, particularly for Britain (above). The key point, however, is that the ranking of countries is the same and the differences between countries are large in both sources.

\section{Determinants of apprentice pay: evidence}

Why would apprentice pay differ across the three countries? Institutional theories emphasise the organized interests of employers and employees, and the mode and content of state intervention. We group the relevant institutional attributes into those three categories. Human capital theory emphasises differences in the skill content of production technologies, the demand for trainees by employers, and the supply of young people to training (Stevens, 1999). In our sample of metalworking employers, however, only supply conditions differ substantially. The demand side is marginalized by the limitation of our sample to employers who train apprentices, and their use of skills and their training programmes are similar across the three countries. The third attribute, the supply of potential trainees, does however differ substantially by country.

Table 2 summarizes the explanatory variables indicated by these theories, and their ratings for the three countries. We do not dichotomize institutions and markets, nor economic and institutional theories, but rather treat all institutional attributes as affecting apprentice pay within training markets. Normally one would analyse intra-country as well as inter-country differences in apprentice pay, but that is not possible as most of our variables are national attributes that vary more between countries than between plants. 
Table 2 about here

\section{Trade unions}

The theories discussed above predict that two aspects of trade unionism affect apprentice pay: collective bargaining coverage, and whether unions seek to raise apprentice (relative) pay. Economywide, bargaining coverage is higher in Germany than in Switzerland or Britain, at 63, 48 and 34 per cent respectively (Visser, 2011). Lacking representative data for metalworking, we turn to our sample of plants. The great majority are covered by a collective agreement, at either sector level (Germany and Switzerland) or company or plant level: seven of the eight establishments in Germany and Britain, and six in Switzerland. However the Swiss sectoral agreement does not cover any pay category; in the absence of effective union representation at the workplace, companies can in effect determine this for themselves (ASM, 2006). Moreover, though apprentice pay was covered by collective bargaining in all seven German plants covered by a collective agreement, this was the case in only one British plant. We therefore rate bargaining coverage for metalworking apprentices 'high' in Germany and 'low' in the other two countries.

We rely on interviews for evidence on trade union objectives. A senior official in the pay policy department of IG Metall states that his union would like apprentices to receive 35 to 40 per cent of the craft rate, rather than 30 to 35 per cent as at present. This reflects the importance the union attaches to the recruitment and integration of young members, as shown by the substantial resources devoted to its internal organization for apprentices and young workers (IGM, 2010). Nevertheless, the union does not give priority to higher pay for apprentices: the desired increase is not large, nor does it currently feature on the list of negotiating demands --- in contrast to the union's contemporary pursuit of a right to an indefinite employment contract for all apprentices on completion of training.

In Switzerland, the leading union, Unia, not only has no role in pay-setting in metalworking, it does not actively seek such a role, particularly for apprentices, nor would it want higher apprentice pay. An official told us that her union would prefer, not a general increase in apprentice pay, but rather increases in the very low rates offered by particular companies, and the payment of a thirteenth month to the one-third of apprentices who do not receive it. She attributes the union's stance both to its concern for the supply of training places and to the weakness of its youth organization, caused partly by a lack of resources for recruiting apprentices.

In Britain, a regional official of Unite, the largest union in metalworking, responsible for pay negotiations in three of the largest plants in our sample, states that, although the union prefers high apprentice pay, it does not actively pursue that goal: it sees no need, given the high rates typically offered by employers. His view is corroborated by managers. A highly unionized pump producer, which no longer negotiates apprentice pay, still pays the high rates of the last (1988) sectoral pay agreement, drawn up when the union was considerably stronger than it is today. The personnel manager confirms that the union's lack of interest in apprentice pay results from the firm's high pay rates.

Apprentice pay might also be influenced by employee representation at the workplace, in works councils or similar bodies --- particularly in Germany, where councils, legally mandated in all but the smallest plants, possess codetermination powers over training, and, despite their formal exclusion from pay setting, informally influence pay at plant level (Thelen, 1991). All our German plants, and almost all our Swiss ones, have a functioning works council. However, in only one case, a British plant with a consultative committee, have workplace representatives shown interest in apprentice pay, as opposed to training methods and a right to employment for apprentices after training. Managers typically attribute lack of interest in apprentice pay to low representation of apprentices, and more fundamentally to lack of discontent about pay among apprentices themselves, in Switzerland as well as Germany. We therefore rate 'low' union interest in raising apprentice pay in Britain and Switzerland, and 'medium' in Germany. 


\section{Employers' associations}

As noted above, economic models commonly assume that trainee pay in the absence of collective bargaining is set by competitive market clearing, but that may not be the case where pay is coordinated by employers' associations. In Switzerland, sectoral associations have an overall coverage rate around 80 per cent at national level, compared to 60 per cent in Germany and only 35 per cent in Britain (Visser, 2011). The same ranking of countries applies in metalworking: the three largest Swiss associations cover at least two-thirds of employment, as against one-half in Germany (according to a senior Gesamtmetall official), and undoubtedly much less in Britain, where sectoral bargaining ended in 1990 and the Engineering Employers' Federation (EEF), having survived large membership losses, now claims to represent only one-quarter of companies. ${ }^{3}$

Employers' associations play central roles in the organization of apprenticeship in both

Germany and Switzerland: they are represented on the sector committees that draw up and revise skill profiles and training ordinances for particular occupations. In Germany, unions have parity of representation on those committees. In Switzerland, by contrast, the employers' association normally is the committee: a government official estimates that around 90 per cent of regulatory committees (Berufsverbände) comprise one or more sectoral employers' associations. Those committees are required to consult other interested parties, including trade unions and educators. However, our interviewees, in government and trade unions alike, see Swiss unions as typically neither wellresourced nor interested enough to participate at sector level, leaving the field in effect to employers' associations --- a view shared by Trampusch (2010) and Gonon and Maurer (2012).

Our evidence points to the coordination of pay-setting in Switzerland by employers' associations. Formally speaking, this is not the case: neither of the two largest metalworking associations-Swissmem for larger companies and Swissmechanic for smaller ones - conducts pay bargaining, nor does either make pay recommendations to its members (Oesch, 2007). Formally, they confine themselves to collecting and compiling data on apprentice pay at establishment level. Informally, however, pay coordination appears important, centred on the circulation to members of the results of their pay surveys. Two well-placed observers --- officials of the federal government and of one metalworking association --- both see these surveys as the means to avoid pay-based competition for apprentices. By contrast, they see non-price competition for potential trainees, on company reputation, the content of training and the timing of recruitment, as widespread and intense.

How might any such pay coordination through employers' associations survive profit-seeking individualism? Extension rules can make an association's recommendations legally binding, on nonmembers as well as members, and that is the case for the content of apprenticeship. But they do not feature in Swiss pay setting. We take employers' cohesion to depend instead on the limited size and strong social norms of Swiss business communities, with their dense networks of associational contacts (Soskice, 1990; Eichenberger and Mach, 2011).

In Germany, employers' associations, which in metalworking means Gesamtmetall and its regional affiliates, also coordinate pay-setting, and do so formally, by formulating a policy to pursue in regional pay negotiations. A growing minority of metalworking firms, including one of our eight plants, avoid coverage by the regional Tarif agreement, but even they are influenced by association policy, whether informally by simply adhering to the agreement, or formally by the extension rule that requires that apprentices receive at least 80 per cent of the relevant Tarif rate (Beicht, 2011). We therefore take employer coordination of pay setting to be high in both Germany and Switzerland.

In Britain, as in Switzerland, in the near absence of collective bargaining over apprentice pay, pay-setting depends on the individual employer, not the employers' association. The EEF also circulates the results of its pay surveys to members, who, according to a senior official, are also concerned to keep apprentice pay in line with other employers in their districts. The difference from Switzerland consists of lower associational coverage, greater territorial dispersion of employers and weaker collective orientation among employers. We take pay coordination by employers' associations 
to be low in Britain. The greater dispersion of apprentice pay across plants in Britain (Table 1) is consistent with this interpretation.

\section{State-related attributes}

The state also influences training markets, whether intentionally or not. In Germany and Switzerland, public subsidies to apprenticeship are channelled through part-time education, paid directly to vocational colleges for courses for which no fees are charged. The costs of workplace training fall generally on the employer and the apprentice. In Britain, metalworking apprenticeship similarly involves part-time vocational education, provided primarily by public colleges, in which fees are either not charged (under-18s) or are publicly subsidized (18 plus). But the mode of public subsidy in the Apprenticeships programme is radically different from the German and Swiss approach. Public money flows in the first instance not directly to colleges but rather to the principal contractor for an Apprenticeship programme as a whole. In metalworking, exceptionally, that is still typically an employer, not a specialist training company, even if employers often contract out such functions as competence assessment and compliance-related paperwork. Substantial subsidy is involved: in 200708 , at least $£ 16,000(€ 21,000)$ for a typical 16-18 year old entrant (Ryan et al., 2011: Table 10). ${ }^{4}$

Although the grant covers less than half the employer's cost for an engineering apprenticeship (Hasluck et al., 2008), and much of that is absorbed by the costs of assessment and administration, it can be expected to raise apprentice pay. The extent to which the subsidy benefits the apprentice rather than the employer increases as the elasticity (responsiveness) of youth supply with respect to apprentice pay falls. By contrast, when public subsidies are paid directly to public colleges, apprentice pay is reduced, to the extent that increased access to free part-time education increases youth interest in taking training and allows employers to fill training places at lower pay than in the absence of the subsidy. The difference between the two scenarios is that, ceteris paribus, the British approach shifts the employers' demand curve up, while the German-Swiss approach shifts the youth supply curve down. As we lack estimates of the elasticities of youth supply and employer demand, the subsidy's quantitative effect on apprentice pay remains uncertain, but the direction of its effect is clear.

Apprentice pay may also be affected by the extent to which the contractual status of apprentices is differentiated from that of regular employees, in both law and practice. When training involves a clear distinction between trainees and employees, both contractually and in production, employers can more easily pay trainees a low rate, as doing so is then legitimated in the eyes of both regular employees and trainees themselves, than when the status of trainees is close to those of regular employees, as in simple on-the-job training, in which the principle is typically 'rate for the job'.

Apprenticeship training potentially satisfies the former conditions (Marsden and Ryan, 1991).

Britain's higher apprentice pay is consistent with its weaker differentiation of apprenticeship from regular employment. Although apprentices in all three countries nowadays have the legal status of employee, in Germany and Switzerland the training contract remains central, with the rights and duties associated with employee status read in as secondary attributes (Ryan, 2012). In both countries the pay of apprentices is formally differentiated from that of employees, as Vergütung in Germany and Lehrlingslohn in Switzerland, by contrast to wages and salaries (Lohn, Gehalt) for employees. Indeed, none of our Swiss employers includes apprentices in its general pay increases for employees, adhering instead to the absolute monthly amounts that must by law be contractually stipulated at the start of training, whereas five of the British and all eight of the German ones do so. The British government has promoted, in both administrative practice and recent legislation, 'employee status' for participants in the Apprenticeships programme. The 2009 Apprenticeships Act stipulates paradoxically that an Apprenticeship agreement constitutes an employment contract, not a contract of apprenticeship, thereby denying Apprentices some rights traditionally enjoyed by apprentices under common law, notably security of tenure during training (Parliament, 2009: 15-16; Ryan, 2012). The convergence of Apprenticeship on regular employment may well contribute to the higher pay of British apprentices. 
Three attributes of national education systems potentially affect apprentice pay, by way of the supply side of training markets. The first is ease of access to full-time upper-secondary education. Switzerland and Germany both have lower-secondary streams that end in school-leaving certificates that promote eligibility for apprenticeship but not (at least, not directly) for full-time upper-secondary general education. Young people are steered at the margin towards apprenticeship through the limitation of places in full-time general programmes, either at lower-secondary (Germany) or uppersecondary (Switzerland) level. In both countries, practice varies territorially (by Land and canton, respectively).

Evidence of rationing at upper-secondary level in Switzerland includes variations in full-time participation across cantons, according to the availability of full-time places (Neuenschwander, 2009; SKBE/CSRE, 2010: Fig 71). Changes over time point in the same direction: the marginal rate of entry to Gymnasium (grammar school) when the youth population cohort expands is only one quarter as large as the average rate (Muehlemann et al. 2009). German evidence shows the importance of pupils' social background in inducing primary teachers to recommend that particular students apply for the lower two streams in lower-secondary schooling even when their grades or personal attributes make them potentially suitable for the top stream (Schnepf, 2002). By contrast, Britain has seen, until recently at least, both a predominance of comprehensive lower-secondary schooling and government promotion of full-time upper-secondary education, by way of school funding mechanisms, grants for 'staying on' at age 16, and reductions of the learning requirements for secondary qualifications (Machin and Vignoles, 2006). The implication is a lower supply of young people to apprenticeship in Britain than in Germany and Switzerland.

The second educational attribute is the mean age of entry to apprenticeship. The older, more educated and more experienced are apprentices, the greater their potential output during training, and, under competitive pay setting, their pay during training. Moreover, older apprentices are less likely to live with their parents and more likely to have dependents of their own, which also increases the minimum pay that will induce them to accept training. The mean age of entry to apprenticeship (all occupations) is nearly two years lower in Switzerland (17.6) than in Britain and Germany (19.3 and 19.4 respectively; Ryan et al., 2010: Table 10). The national pattern is mirrored in metalworking. The principal age of entry is 15-17 in all of our Swiss establishments, and in most British and German ones as well (11 out of 16), but almost one-third of the British and German plants recruit primarily at age 18-20, and the same share take on at least some adults (>20 years; Ryan et al., 2011: Table 12). The difference between Switzerland and the two other countries is associated with a lower minimum school leaving age than in Britain (15 versus 16 years), and a higher rate of direct movement from lower-secondary schooling to apprenticeship than in Germany, where most young people nowadays complete post-lower-secondary schooling (Realschule or Gymnasium) before starting apprenticeship. The lower age of Swiss apprentices promotes lower apprentice pay than in Britain and Germany.

The third educational attribute is the scope for progression from apprenticeship to tertiary education, for which Switzerland again stands out. Swiss apprentices can study part-time for a vocational upper-secondary qualification (Berufsmaturität) that gives the right to enter full-time tertiary education. Around 12 per cent of apprentices do so, whether during training or afterwards (BBT, 2010). The option increases the appeal of apprenticeship to young people, particularly more ambitious and able ones - and it was introduced in 1994 to do just that (Gonon and Maurer, 2012). Neither Germany nor Britain has yet developed a full counterpart. In Germany, educational progression from apprenticeship requires either the acquisition of a further school-based qualification (Fachoberschulreife), which has only recently and in some Länder been made available during rather than after apprenticeship, or the possession before entry of the upper-secondary general qualification (Abitur; Nikolai and Ebmer, 2012). Similarly, although some of our British companies have informally established progression ladders that comprise tertiary qualifications for their apprentices, the sector still lacks options for ambitious apprentices to qualify for full-time higher education during training.

Differences in the ease of remaining in full-time schooling, the age of apprentices and options for educational progression all differentiate the national supply of young people to apprenticeship, and 
thus potentially also the pay of apprentices. Switzerland and Britain occupy the opposite poles on all three factors, with Germany standing closer to Switzerland on the first one and closer to Britain on the other two.

\section{Market conditions}

The final group of potential influences on training markets comprises three variables that do not in principle depend directly on trade unions, employers' associations or the state. The first concerns educational outcomes and youth motivation; the other two, conditions in related markets.

The supply of potential apprentices depends not only on the structural attributes of national educational systems but also on educational outcomes within those structures: specifically, the qualifications and motivation of school-leavers. We rely here on interview evidence. The British employers in our sample report lower ratios of acceptable applications to apprenticeship vacancies than do the German and Swiss. Acceptable applications exceed vacancies in all three countries, with mean ratios of 3.2, 11.6 and 7.2 respectively. However, the lower British ratio allows employers less scope to choose among applicants. Three of them express particular concern about the supply of applicants, which they attribute variously to: low educational attainments, particularly in science and mathematics; the sector's record of employment decline and redundancy; the low status of craft apprenticeship in the eyes of many parents and teachers; and a widespread preference for full-time education among the more qualified 16-18 year olds.

Differences within countries are also marked. Two large British turbine manufacturers with strong corporate reputations attract a large number of acceptable applications, despite accounting for a considerable share of local employment. Nor are all German and Swiss firms free from supply problems. A German turbine manufacturer, based in a city with high unemployment, opted in a recent year, given disappointing applications, not to fill any of its few vacancies for apprentices. Two of the three smallest plants in the Swiss sample reported at most two acceptable applicants per vacancy.

Apprentice pay is expected to depend also on conditions in two related markets, those for unskilled and for skilled labour. Human capital theory sees the market for unskilled labour as providing school-leavers with the principal alternative to apprenticeship. In Britain, although opportunities for unskilled youth employment have shrunk since the 1970s (Roberts, 1995), an experienced official of the Sector Skills Council sees them as still extensive enough to compete with apprenticeship, in terms of both availability and appeal. Low-skilled work is also available to young people in Germany and Switzerland, particularly in the service sectors of large urban areas. Our interviewees emphasise however the high social value attached to possession of a skilled occupational qualification (Berufsprinzip) as reducing interest in such work among school-leavers. We therefore rate this factor as promoting lower youth supply to apprenticeship in Britain.

Finally, conditions in the market for skilled labour are expected in human capital theory to shape expectations among would-be apprentices concerning the gain in lifetime earnings derived from training, which comprises both higher employment probability and higher pay when employed, as compared to having chosen less-skilled employment instead. The larger both are, the lower the pay that young people will rationally accept during training. (We exclude here prospects for subsequent occupational progression from skilled occupations, for which few data are available.)

Recent levels of skilled pay and unemployment may be taken to dominate the expectations of young people. The differential between skilled and semi-skilled pay in metalworking is similar in Switzerland and Britain, 36 and 32 per cent respectively, and lower in Germany, 14 per cent (Ryan et al., 2011: Table 27). Fewer data are available for expectations of being in work, and in all three countries some worsening must have occurred, associated with industrial restructuring and extensive redundancies. In the absence of unemployment data at sector-occupation level, we turn to national unemployment rates, which, during 1998-2007 averaged 5.3, 9.2 and 3.3 per cent in Britain, Germany and Switzerland respectively. Considering both pay differentials and unemployment experience, we therefore rate the expected private return to training (in pecuniary terms, and excluding the social 
status of skill) as higher in Switzerland than in Germany and Britain. Expectations of a higher financial return to training are therefore consistent with lower pay for Swiss than for German and British apprentices.

\section{Interpretation}

With three observations and twelve potential determinants, no definitive analysis of causality is possible, as is often the case in comparative research. Progress may however be possible, by grouping variables and using analytical comparative methods.

If the explanatory variables are grouped, in this case by institutional category, and if all variables in a group have the same predicted effect on the dependent variable in a particular comparison, the group can be treated as a single composite variable. The relative contribution of the component variables cannot be determined, but their combined effect may be visible. The relevant comparative methodology is Mill's method of difference, applied to pair-wise comparisons of countries. Analytically the most favourable situation involves two countries for which all but one of the independent variables (or groups of variables) take the same values. The difference in national outcomes can then be attributed to the difference in that variable (or variable group). ${ }^{5}$ We now consider the three possible pair-wise national comparisons, using the four variable groups in Table 2 . Table 3 shows the predicted effect on apprentice pay of the ratings assigned to the variable groups in particular pair-wise comparisons.

Table 3 about here

Mill's ideal is almost realised in the German-Swiss comparison. The values taken by most of the variables in three of the groups --- employers' associations, state-related and training markets --are rated 'same' in both countries, and are therefore ruled out as causes of the difference in apprentice pay. By contrast, trade unionism differs markedly, and its predicted effect on pay has the right sign: in Germany, both bargaining coverage and union interest in raising apprentice pay are greater than in Switzerland, and both variables promote higher apprentice pay (Dionisius et al., 2009).

Nevertheless, trade unionism cannot be taken to be the sole cause of the pay difference between the two countries. Some variables in the other three groups also differ, and do so in a manner consistent with the difference in relative pay: specifically, Germany's lower coverage by employers' associations, higher mean age of entry, weaker progression options and lower private returns. The inference is that some mixture of these differences and those in the two trade unionism variables generates the difference in pay between the two countries, though the relative importance of those six variables cannot be determined.

The British-Swiss comparison, by contrast, involves almost the exact opposite of Mill's ideal: differences in all explanatory groups except one. Even so, some explanatory insight can be achieved. As there is no major difference in the trade unionism group, causality cannot be sought here. However, all ten variables in the other three groups promote higher pay in Britain. We infer therefore that some combination of those ten variables causes the pay difference. The inference is again weak, in that the relative importance of individual variables cannot be determined. However, as all ten take values consistent with higher pay in Britain, and assuming that most or all of them make some contribution to the difference in pay, a remarkable congruence can be inferred: complementarities within a range of institutional and market attributes, not necessarily in the strong sense that their effects interact, though that may be so, but at least in the simultaneous presence of all of them, which is unlikely to be purely coincidental (Crouch, 2010).

Finally, the British-German comparison sees the same contrast in three of the variable groups (employers, state, and market conditions) as in the British-Swiss one, reflecting the similarity of Germany and Switzerland on most variables. Age of entry, progression options and private returns to training are rated 'same' and can therefore be ruled out as causes. But the difference in trade unionism 
is predicted to favour lower pay in Britain. The combined effect of differences in the other variables (employers, subsidy mode, contractual status, educational access, lower secondary attainments, appeal of unskilled work) are therefore taken to outweigh trade unionism in causing higher pay in Britain.

A further inference becomes possible when the three pair-wise comparisons are considered together. Taking Switzerland as the base case, the larger difference in apprentice pay relative to Britain than to Germany suggests that the many attributes, related to employers' associations, the state and the training market, that are taken to generate higher pay in Britain are jointly more powerful than trade unionism as causes of higher apprentice pay. The inference is consistent with the view that German unions have opted not to use their power to the full when negotiating apprentice pay.

Our evidence cannot identify any hierarchical relationships among the explanatory variables. For instance, contractual status may interact with market conditions. The British government has promoted employee status for Apprentices in order to improve the programme's appeal to young people, by dissociating it from the poor reputation of antecedent labour market programmes. Contractual status therefore partly reflects political concerns about youth supply to training.

\section{Conclusions}

We draw on both economic and institutionalist theories of training to investigate why apprentice pay in metalworking is higher in Britain than in Germany, and lower in Switzerland. The evidence clearly contradicts the hypothesis that Britain, as a liberal market economy, would have lower pay than Germany and Switzerland, as coordinated market economies. Higher apprentice pay in Britain is attributed to a range of factors, including both the institutional thinness of a liberal market economy (weakness of trade unions, employers' associations, and the education system) and the balance of supply and demand in markets for training places (in particular, shortages of qualified and interested applicants). The contribution of individual variables cannot be determined from our evidence, but their combined effect is strong.

Low apprentice pay in Switzerland is attributed primarily to low bargaining coverage and trade union passivity (relative to Germany in particular), accompanied by informal, monopsonistic pay-setting by employers, and to key attributes of the education system, notably the steering of school pupils away from full-time upper secondary studies and the erection of ladders for educational progression from apprenticeship. The impressive range of state-related, educational and market factors that buttress apprenticeship in Switzerland, and to a lesser extent in Germany, suggests important complementarities among those factors, which may well be necessary for the two most successful apprenticeship systems in the modern world to combine large volume and high quality while avoiding high apprentice pay.

The additional ingredients in the Swiss case are the near-absence of collective bargaining over apprentice pay, which permits unilateral coordination by employers' associations; lower age of entry; easier educational progression from apprenticeship; and higher private returns to training. The lower cost of training to employers and the larger scale of apprenticeship in Switzerland than in Germany reflect these differences.

The evidence is not consistent with the assumption, made in some economic models, that trade unions invariably reduce pay differentials between trainees and skilled workers. The assumption was relevant historically in British and German metalworking, but it is no longer appropriate. $I G$ Metall does prefer higher apprentice pay, but not much higher, and does not make it an active negotiating demand. Its Swiss counterpart would not want to raise apprentice pay, even had it the power to do so, for fear of reducing the supply of training places.

The limitations of our results include the impossibility of establishing from them the separate contributions of the various determinants of apprentice pay, particularly higher pay in Britain. There is also the standard problem in cross-sectional research, of holding constant unmeasured national attributes, notably culture and social values, which potentially include greater adult support for slow maturation by young people in Switzerland than in Britain. Finally, employer demand for skill may 
well be lower in British metalworking - though that would reinforce, not contradict, the dominance of supply factors, as depressed demand would favour lower apprentice pay in Britain.

Can these findings be generalized to other sectors? The comparative pay pattern is certainly representative for the three economies as a whole, with many of these institutional and market attributes also featuring. The analysis must however differ somewhat for other sectors, as the learning content of most of Britain's Apprenticeship programme is much lower than its Germanic counterparts, and higher trainee pay is to be expected on that ground alone.

At least two issues deserve further research. The first is the extent and methods of informal pay coordination by employers' associations. The second is the intentionality and coherence of public action, which may well differ more generally between coordinated and liberal market economies. The coherence of public support for apprenticeship in Switzerland, with the early introduction of the Berufsmaturität, contrasts with the piecemeal expediency shown by the British government, with its denial to Apprentices of the common-law status of apprentice.

Finally, these results might suggest that British metalworking apprenticeship is handicapped by high apprentice pay. That view would align with the Swiss union's aversion to raising pay for fear of reducing training volume. The effect of higher trainee pay on training is however disputed, as the evidence is limited, and some economic models predict more training as a result of higher pay (Acemoglu and Pischke, 1999; Ryan, 2010; Stevens, 1994). We see apprentice pay as depending on the many factors that affect supply, demand, and price setting in training markets. The responsiveness of employers to apprentice pay may well be low, but that constitutes only one of the factors influencing apprentice pay. Indeed, were demand and supply to be both unresponsive to apprentice pay, as appears likely, and cyclically variable, as is clearly the case, then even in a liberal market economy like the UK employers would undoubtedly strive to avoid the large pay fluctuations that would be required by continuous market-clearing.

\section{Acknowledgements}

Our thanks to two referees and the editor. Full acknowledgements are in Ryan et al. (2011).

\section{Funding}

We thank the Hans-Böckler-Stiftung, Anglo-German Foundation, SKOPE (Oxford), the Swiss federal government (OPET/SERI) and WZB (Berlin) for financial support.

\section{Notes}

${ }^{1}$ Lacking official data on apprentice stocks for Britain, we estimate the number of engineering Level 3 apprentices (for December 2007) from new entries during the previous four years and completions during a subsequent (four year lagged) period. Details are available from the authors.

${ }^{2}$ Earnings-based measures of pay are preferable in principle (Ryan, 2010) but are available from national surveys only for Switzerland.

${ }^{3}$ www.eef.org.uk/about/How+we+work/.

${ }^{4}$ The advent of the Apprenticeships programme has meant for most occupations a need to distinguish between 'apprenticeship' (functional category) and 'Apprenticeship' (labour market programme). In Level 3 metalworking occupations, however, the two definitions align closely, as the requirements of the Apprenticeships programme satisfy standard functional definitions, and almost all apprentices nowadays come under this programme (Ryan et al., 2007; Ryan, 2012).

${ }^{5}$ Although some variables, including apprentice pay, are quantitative, most are qualitative, so we cannot use Mill's method of concomitant variation, and discard some quantitative information in pursuit of analytical traction (Moses and Knutson, 2007: 94-115). 


\section{References}

Acemoglu D and Pischke J-S (1999) Beyond Becker: Training in imperfect labour markets. Economic Journal 108: F112-42.

ASM (2006) Agreement in the Mechanical and Electrical Engineering Industries. Zurich: ASM.

Backes-Gellner U and Mohrenweiser J (2010) Apprenticeship training - what for? Investment in human capital or substitute for cheap labour? International Journal of Manpower 31(5): 54562.

BBT (2010) Berufsbildung in der Schweiz: Fakten und Zahlen. Bern: Bundesamt für Berufsbildung und Technologie.

Becker G (1964) Human Capital. New York: NBER.

Beicht U (2011) Langzeitentwicklung der tariflichen Ausbildungsvergütung in Deutschland. Wissenschaftliche Diskussionspapiere 123. Bonn: BIBB.

BMBF (1999) Bündnis für Arbeit, Ausbildung und Wettbewerbsfähigkeit. Berlin: Presse- und Informationsamt der Bundesregierung.

Busemeyer M and Trampusch C (2012) The comparative political economy of collective skill formation. In Busemeyer and Trampusch (eds) The Political Economy of Collective Skill Formation. Oxford: OUP, pp.3-40.

Crouch C (2010) Complementarity. In Morgan G, Campbell J, Crouch C and Pedersen OK (eds) Oxford Handbook of Comparative Institutional Analysis. Oxford: OUP, pp.117-38.

Crouch C, Finegold D and Sako M (2001) Are Skills the Answer? Oxford: OUP.

Dionisius R, Mühlemann S, Pfeifer H, Walden G, Wenzelmann F and Wolter SC (2009) Costs and benefits of apprenticeship training. A comparison of Germany and Switzerland. Applied Economics Quarterly 55(1): 5-38.

Eichenberger P and Mach A (2011) Organised capital and coordinated market economy: Swiss business interest associations between socio-economic regulation and political influence. In Trampusch C and Mach (eds) Switzerland in Europe. London: Routledge, pp.63-81.

Garonna P and Ryan P (1991) The regulation and deregulation of youth economic activity. In Ryan, Garonna and Edwards RC (eds) The Problem of Youth. London: Macmillan, pp.35-81.

Gonon, P and Maurer M (2012) Educational policy actors as stakeholders in the development of the collective skill system: the case of Switzerland. In Busemeyer M and Trampusch C The Political Economy of Collective Skill Formation. Oxford: OUP, pp.126-49.

Hall P and Soskice D (2001) Varieties of Capitalism. Oxford: OUP.

Hasluck C, Hogarth T and Adam D (2008) The Net Benefit to Employer Investment in Apprenticeship Training. Coventry: Institute for Employment Research, University of Warwick.

Hyman R (2001) Understanding European Trade Unionism. London: Sage.

IGM (2010) Jugendseminare der IG Metall. Frankfurt: IG Metall.

Leuven E (2005) The economics of private sector training: a survey of the literature. Journal of Economic Surveys 19(1): 91-111.

Machin S and Vignoles A (2006) Education policy in the UK. Discussion Paper 57, Centre for the Economics of Education. London: London School of Economics.

Manning A (2003) Monopsony in Motion. Princeton: Princeton University Press.

Marsden DW and Ryan P (1991) The structuring of youth pay and employment in six European economies. In. Ryan, Garonna P and Edwards RC (eds) The Problem of Youth. London: Macmillan, pp.82-115.

Moses JW and Knutsen TL (2007) Ways of Knowing. Competing Methodologies in Social and Political Science. London: Palgrave Macmillan.

Muehlemann, S, Ryan P and Wolter SC (2013) Monopsony power, pay structure and training. Forthcoming, Industrial and Labour Relations Review.

Muehlemann S, Wolter SC and Wüest A (2009) Apprenticeship training and the business cycle. Empirical Research in Vocational Education and Training 1(2): 173-86.

Neuenschwander MP (2009) Systematisch benachteiligt? Ergebnisse einer Schweizer Studie zu Bildungssystem und -beteiligung. Pädagogische Führung 3: 132-5. 
Nikolia R and Ebmer C (2012) The link between vocational training and higher education in Switzerland, Austria and Germany. In Busemeyer M and Trampush C (eds), The Political Economy of Collective Skill Formation. Oxford: OUP, pp.234-58.

Oesch D (2007) Weniger Koordination, mehr Markt? Kollektive Arbeitsbeziehungen und Neokorporatismus in der Schweiz seit 1990. Swiss Political Science Review 13(3): 337-68. Parliament (2009) Apprenticeships, Skills, Children and Learning Act 2009. London: Parliament. Popiunik M and Ryan P (2012) Improving the transition between education and the labour market. Report to the European Expert Network on the Economics of Education. IFO, University of Munich.

Roberts K (1995) Youth and Employment in Modern Britain. Oxford: OUP.

Ryan P (1987) Trade unionism and the pay of young workers. In Junankar P (ed.) From School to Unemployment? London: Macmillan, pp.119-42 .

Ryan P (2010) Apprentice strikes, pay structure, and training in twentieth century UK metalworking industry. In Brown C, Eichengreen B and Reich M (eds) Labour in the Era of Globalisation. Cambridge: CUP, pp.317-50.

Ryan P (2012) Apprenticeship: between theory and practice, school and workplace. In Pilz M (ed.) The Future of VET in a Changing World. Wiesbaden: Springer, pp.403-32.

Ryan P, Gospel H and Lewis P (2007) Large employers and apprenticeship training in Britain. British Journal of Industrial Relations 45(1): 127-53.

Ryan P, Wagner K, Teuber S and Backes-Gellner U (2010) Trainee pay in Britain, Germany and Switzerland: markets and institutions. Research Paper 96. Cardiff: SKOPE, Cardiff University.

Ryan P, Wagner K, Teuber S and Backes-Gellner U (2011) Financial Aspects of Apprenticeship Training in Germany, Great Britain and Switzerland. Arbeitspapier 241. Dusseldorf: Hans Böckler Stiftung.

Schnepf, SV (2002) A sorting that fails? The transition from primary to secondary school in Germany. Working Paper 92, Florence: UNICEF Innocenti Research Centre.

SKBF/CSRE (2010) Bildungsbericht Schweiz 2010. Aarau: Schweizerische Koordinationalstelle für Bildungsforschung.

Soskice D (1990) Wage determination: the changing role of institutions in advanced industrialised economies. Oxford Review of Economic Policy 6(4): 36-61.

Soskice D (1994) Reconciling markets and institutions: the German apprenticeship system. In Lynch L (ed.) Training and the Private Sector. Chicago: University of Chicago Press, pp.25-60.

Steedman H (2008) Time to look again at apprentice pay. SSDA Catalyst 1: 1-17.

Steedman H (2010) The State of Apprenticeship in 2010. London: Centre for Economic Performance, London School of Economics.

Stevens M (1994) A theoretical model of on-the-job training. Oxford Economic Papers 46(4): 537562.

Stevens M (1999) Human capital theory and UK vocational training policy. Oxford Review of Economic Policy 15: 16-32.

Streeck W and Yamamura K (eds) (2001) The Origins of Non-Liberal Capitalism. Cornell: Cornell University Press.

Thelen K. (1991) Union of Parts. Ithaca, NY: Cornell University Press.

Thelen K (2004) How Institutions Evolve. Cambridge: CUP.

Trampusch C (2010) Employers, the state and the politics of institutional change: vocational education and training in Austria, Germany and Switzerland. European Journal of Political Economy 49(4): 545-73.

Traxler, F, Blaschke S and Kittel B (2001) National Labour Relations in Internationalised Markets. Oxford: OUP.

Turner L (2009) Institutions and activism: crisis and opportunity for a German labour movement in decline. Industrial and Labour Relations Review 63(2): 294-312.

Unia (2008) 13.Monatslohn für alle Lehrlinge!, Lehrlingslohn, 31 December (www.lehrlingslohn.ch). 
Visser J (2011), ICTWSS: Database on Institutional Characteristics of Trade Unions, Wage Setting, State Intervention and Social Pacts 1960-2010. Institute for Advanced Labour Studies, University of Amsterdam.

Wagner K (1999) The German apprenticeship system under strain. In Culpepper P and Finegold D (eds) The German Skills Machine. New York: Berghahn, pp.37-76.

Woessman L (2004) Berufsausbildung - einige Anmerkungen zu den Ursachen des Ausbildungsplatzmangels. IFO Schnelldienst 6/2004: pp.21-24.

Wolter SC and Ryan P (2011) Apprenticeship. In Hanushek R, Machin S and Woessman L (eds) Handbook of the Economics of Education, Vol. 3. Amsterdam: Elsevier, pp.521-56.

\section{Author biographies:}

Paul Ryan is Fellow of King's College Cambridge.

Uschi Backes-Gellner is Professor in the Department of Business Administration at the University of Zurich and Director of the Swiss Leading House on the Economics of Education.

Silvia Teuber holds a PhD in business economics from the University of Zurich and has been researcher at the Swiss Leading House on the Economics of Education.

Karin Wagner is Professor at HTW Berlin, specialising in human capital and economic performance, and in production, logistics and health services management. 
Table 1. Attributes of metalworking establishments studied ${ }^{a}$

\begin{tabular}{|c|c|c|c|c|c|c|c|c|}
\hline \multicolumn{2}{|c|}{ Employment $^{\mathrm{b}}$} & \multicolumn{3}{|c|}{ Number of apprentices ${ }^{c}$} & \multicolumn{2}{|c|}{ Training attributes } & \multicolumn{2}{|c|}{$\begin{array}{l}\text { Relative pay of } \\
\text { apprentices }^{\mathrm{d}}\end{array}$} \\
\hline \multirow[t]{2}{*}{ Median } & \multirow[t]{2}{*}{$\begin{array}{l}\text { Share of } \\
\text { parent }(\%)\end{array}$} & \multirow[t]{2}{*}{ Mean } & \multicolumn{2}{|c|}{$\begin{array}{l}\text { Ratio to production } \\
\text { employment }(\%)\end{array}$} & \multirow{3}{*}{$\begin{array}{l}\text { Duration } \\
\text { of training } \\
\text { (years) } \\
3.5\end{array}$} & \multirow{2}{*}{$\begin{array}{l}\text { Off-the-job } \\
\text { share year } 1 \\
(\%)\end{array}$} & & \\
\hline & & & Mean & SD & & & Mean & SD \\
\hline 377 & 4.7 & 30 & 7.2 & 5.6 & & 81 & 63.5 & 13.1 \\
\hline 500 & 10.5 & 68 & 7.8 & 8.2 & 3.5 & 91 & 33.4 & 4.5 \\
\hline 80 & 9.6 & 39 & 12.8 & 10.3 & 4.0 & 81 & 19.5 & 2.9 \\
\hline
\end{tabular}

Note.

a. Eight plants per country, matched across countries.

b. All occupations.

c. Craft occupations in production and maintenance, including Engineering Maintenance (GB), Industriemechaniker, Mechatroniker (DE), and Polymechaniker (CH).

d. Unweighted mean base pay rates for four training years, relative to that of recently qualified skilled employees in same occupation. 
Table 2. Ratings of potential determinants of apprentice pay

GB

$\mathrm{DE}$

$\mathrm{CH}$

Trade unions

Bargaining coverage for apprentices

Interest in raising apprentice pay

$\begin{array}{lll}\begin{array}{l}\text { low } \\ \text { low }\end{array} & \begin{array}{l}\text { high } \\ \text { medium }\end{array} & \begin{array}{l}\text { low } \\ \text { low }\end{array} \\ \begin{array}{l}\text { low } \\ \text { no }\end{array} & \begin{array}{l}\text { medium } \\ \text { yes }\end{array} & \begin{array}{l}\text { high } \\ \text { yes }\end{array}\end{array}$

Membership coverage, metalworking

Coordination of pay-setting

no

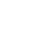

no

Public subsidies paid direct to employers

yes

high

no

low

Closeness of contracts (apprenticeship and employment)

Constraints on access to general upper-secondary education

weak

low

strong

strong

Mean age of entry to apprenticeship

high

high

low

Options for educational progression from apprenticeship

low

low

high

Market conditions

Availability of qualified and interested youth

low

high

high

Unskilled labour market for youth as alternative

yes

no

no

Private pecuniary return to training

low

low

high 
Table 3. Actual and predicted levels of apprentice pay, by variable group, in pair-wise national comparisons

Comparative level of apprentice relative pay in the first of the two countries that is predicted by the values of that variable group (or particular variables within the group)

Actual Predicted

Trade unions $\begin{aligned} & \text { Employers' } \\ & \text { associations }\end{aligned}$ State-related $\begin{aligned} & \text { Market } \\ & \text { conditions }\end{aligned}$

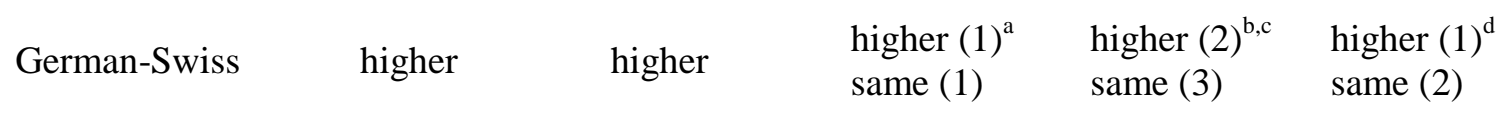

British-Swiss higher $\quad$ same higher higher

\begin{tabular}{|c|c|c|}
\hline h-Germa & higher & lower \\
\hline
\end{tabular}

Note. Parentheses show the number of variables within the group with that predicted effect (for groups in which not all variables have the same predicted effect).

a. employers' association coverage.

${ }^{\text {b. }}$ mean age of entry.

c. educational progression options.

d. private return to training. 